\title{
MULTIKULTURALISME DALAM PENDIDIKAN AGAMA ISLAM DAN IMPLEMENTASINYA DI SMA NEGERI 3 LUMAJANG
}

\author{
Ubaidillah \\ Institut Agama Islam Negeri Jember, Indonesia \\ E-mail: ubed21072011@gmail.com \\ Khilmiyatul Khumidat \\ Institut Agama Islam Syarifuddin Lumajang, Indonesia \\ E-mail: khumidatkhilmiyatul@gmail.com
}

\begin{abstract}
Abstrak: Tulisan ini ingin melihat bagaimana implementasi nilai-nilai multikulturalisme dikembangkan terutama dalam pendidikan agama di Sekolah Menengah Atas Negeri 3 di Lumajang. Seperti diketahui, di sekolah terdapat mata pelajaran pendidikan agama dan terdapat peserta didik yang memiliki perbedaan agama. Multikulturalisme merupakan realitas kehidupan masyarakat dan bangsa, meskipun tidak setiap subyek masyarakat atau bangsa ini mau mengakui dan menerimanya, namun semua meyakini bahwa multikulturalisme sebagai sebuah ideologi akan mengakui dan mengagungkan perbedaan dalam kesederajatan baik secara individual maupun secara kultural dan kelompok. Penelitian ini menggunakan pendekatan kualitatif, data dikumpulkan dengan observasi, interview dan dokumentasi. Penelitian dilakukan di Bulan Maret dan April 2018. Hasil penelitian menunjukkan bahwa nilai multikultural yang ada di SMA Negeri 3 Lumajang mengacu pada nilai-nilai universal dalam masing-masing agama seperti kebersamaan, keadilan, kesetaraan dan kesamaan, sekalipun terdapat berbagai perbedaan agama, suku, dan budaya. Selain itu, implementasi nilai multikultural dalam pendidikan agama Islam dilakukan melalui kegiatan pembiasaan. Salah satu faktor pendukung implementasi multikultural di SMA Negeri 3 adalah adanya antusias peserta didik dan kesadaran peserta didik tentang pentingnya implementasi nilai multikulturalisme.
\end{abstract}

Kata Kunci: Multukulturalisme, Pendidikan Agama Islam

\section{Pendahuluan}

Sebagaimana maklum, Indonesia merupakan salah satu negara dengan komunitas masyarakat majemuk dan multikultural terbesar di dunia, hal tersebut dapat dilihat dari kondisi sosio-kultural maupun geografis yang begitu beragam dan luas. ${ }^{1}$ Saat ini jumlah pulau yang ada di wilayah Negara Kesatuan Republik Indonesia (NKRI) sekitar 13.000 pulau besar dan kecil. Populasi penduduknya berjumlah lebih dari 200 jiwa, terdiri dari 300 suku yang menggunakan hampir 200 bahasa yang berbeda. Selain itu mereka juga menganut agama dan kepercayaan yang beragam

\footnotetext{
${ }^{1}$ M. Ainul Yakin, Pendidikan Multikultural (Yogyakarta: Pilar Media, 2005), 4. 
seperti Islam, Kristen, Hindu, Budha, Konghuchu serta berbagai macam aliran kepercayaan. $^{2}$

Dengan kondisi negara yang majemuk tersbut, pendidikan diharapkan dapat memberikan sumbangan yang besar terhadap kemajuan suatu bangsa dan merupakan wahana dalam menerjemahkan pesan-pesan konstitusi serta modal dasarmembangunwatak bangsa. Masyarakat yang cerdas akan memberikan nuansa kehidupan cerdas pula, dan juga sebaliknya, dan secara progresif akan membentuk kemandirian pada masyarakat itu. ${ }^{3}$

Multikulturalisme dapat berarti keragaman budaya dan plural. Istilah plural mengandung arti berjenis-jenis, karena pluralisme bukan berarti sekedar pengakuan adanya hal-hal yang berjenis-jenis, tetapi juga pengakuan tersebut mempunyai implikasi-implikasi politis, sosialdan ekonomi. Oleh sebab itu pluralisme dapat dipastikan berkaitan dengan prinsip-prinsip demokrasi. Banyak negara menyatakan diriya sebagai negara demokrasi namun tidak mengakui adanya pluralisme didalam kehidupannya sehingga terjadi berbagai jenis segresi. ${ }^{4}$

Keadaan multikultural yang dimiliki Indonesia merupakan salah satu bentuk anugerah, karena dengan begitu Indonesia menjadi negara yang sangat unik dan menarik, namun hal tersebut juga dapat menjadi ancaman bagi Indonesia sendiri, jika tidak dapat menyikapinya secara adil dan seimbang. Karena keunikan dan kekayaan budaya tersebut berpotensi untuk terjadinya disintegrasi. Dimana realita konflik itu telah memunculkan kerusuhan, saling menghasut, caci maki, pertentangan batin, mengusir, membakar dan yang paling berbahaya ketika konflik ini berkepanjanganakan menyisakan tragedi. ${ }^{5}$

Oleh karena itu, nilai multikulturalisme harus dikembangkan agar memiliki pengetahuan yang cukup sehingga memiliki sikap toleransi terhadap perbedaan yang ada di lingkungan sekitar. Dengan demikian, kita dapat meminimalisir perbedaan atau

2 Muhammad Tholchah Hasan, Pendidikan Multikultural Sebagai Opsi Penanggulangan Radikalisme (Malang: Lembaga Penerbitan Universitas Islam Malang, 2016), 13.

${ }^{3}$ Mulyasa, Manajemen Berbasis Sekolah (Bandung: Remaja Rosdakarya, 2002), 4.

${ }^{4}$ H.A.R Tilaar, Multikulturalisme (Jakarta: PT. Grasindo, 2004), 82.

5 Siti Fatimah, Gender dan Pendidikan Multikultural (Jakarta: Kencana, 2016), 14. 
bahkan konflik yang terjadi di lingkungan kita sehingga kita tetap dapat menjaga keutuhan bangsa Indonesia.

Bermula dari kesadaran internal SMA Negeri 3 Lumajang untuk meminimalisir perbedaan tersebut di atas, maka civitas akademika melakukan penanaman, pemahaman dan peningkatan nilai multikuturalisme dalam Pendidikan Agama Islam. Hal ini dilakukan agar para peserta didik tidak larut dalam dunia pergaulan yang salah dan terlibat konflik. Selain itu, sudah sepantasnya sebagai pendidik sepatutnya mengarah pada penanaman, pemahaman dan penghayatan nilai multikultural dalam setiap proses pembelajarannya.

Sikap saling menerima, menghargai nilai, budaya, keyakinan yang berbeda tidak otomatis akan berkembang sendiri. Apalagi karena dalam diri seseorang ada kecenderungan untuk mengharapkan orang lain menjadi seperti dirinya. Sikap saling menerima dan menghargai akan cepat berkembang bila dilatihkan dan dididikkan pada generasi muda dalam sistem pendidikan nasional. Dengan pendidikan, sikap penghargaan terhadap perbedaan yang direncana baik, generasi muda dilatih dan disadarkan akan pentingnya penghargaan pada orang lain dan budaya lain bahkan melatihnya dalam hidup sehingga sewaktu mereka dewasa sudah mempunyai sikap itu. ${ }^{6}$ Dengan mengimplementasikan nilai multikultural dalam pendidikan semua siswa memperoleh kemampuan untuk mengfungsikan dirinya secara efektif dalam situasi lintas budaya, lintas agama, lintas etnik dan lain-lain. ${ }^{7}$

Salah satu tempat atau wadah yang di dalamnya terdapat banyak perbedaan suku, ras, bahasa dan agama adalah tempat pendidikan atau sekolah, karena di sekolah terdapat siswa, guru dan karyawan yang berasal dari latar belakang yang berbeda. Sesuai dengan Undang-undang Republik Indonesia nomor 14 tahun 2005 tentang Guru dan Dosen menyatakan bahwa pembangunan Nasional dalam bidang pendidikan adalah Upaya untuk mencerdaskan kehidupan bangsa dan meningkatkan kualitas manusia Indonesia yang beriman, bertaqwa, dan berahlak mulia serta menguasai ilmu pengetahuan, teknologi, dan seni dalam mewujudkan masyarakat

${ }^{6}$ Ibrahim Ruslan,'Pendidikan Multikultural", El Tarbawi Jurnal Pendidikan Islam, Vol. 1, 2008,117.

7 Zakiyyudin Baidhawy, Pendidikan Agama Berwawasan Multikultural (Jakarta: ERLANGGA), 10.

130 | Tarbiyatuna: Jurnal Pendidikan Islam; Volume 11, Nomor 2, Agustus 2018 p-ISSN: 2085-6539; e-ISSN: 2242-4579 
yang maju, adil dan makmur dan beradap berdasarkan Pancasila dan Undang-undang Dasar Republik Indonesia tahun $1945 .^{8}$

Tugas guru sebagai pengemban amanat pendidikan memang berat, mereka telah menerima amanat dari banyak pihak untuk membentuk seorang peserta didik menjadi lebih baik, berbudi pekerti dan berkepribadian yang luhur. Selain itu guru juga diharapkan menjadi orang tua kedua bagi peserta didik, oleh karenanya guru membimbingnya sehingga menjadi anak yang berubah dalam segala hal dan kaya akan pengetahuan yang tidak diperolehnya dari rumah.

Karena pendidikan merupakan salah satu hal penting dan agama adalah bagian dari salah satu keragaman yang ada maka dalam pendidikan agama juga perlu dikembangkan nilai multikulturalisme. Dengan demikian nilai multikulturalisme dalam pendidikan harus dikembangan dalam pendidikan agar nilai-nilai tersebut sudah tertanam dalam hati sanubari sejak usia dini.

\section{Multikulturalisme dalam Kajian Teoritik}

1. Model-model multikulturalisme

Indonesia adalah salah satu negara yang multikultural terbesar di dunia. Kenyataan ini dapat dilihat dari sosiokultur maupun geografis yang begitu luas dan beragam. Multikulturalisme merupakan realitas kehidupan masyarakat dan bangsa, meskipun tidak setiap subyek masyarakat atau bangsa ini mau mengakui dan menerimanya.

Suparlan mengutip Fay, Jary, Watson dan Reed menyebutkan bahwa multikulturalisme ini akan menjadi acuan atau referensi utama bagi terwujudnya masyarakat multikultural, karena multikulturalisme sebagai sebuah ideologi akan mengakui dan mengagungkan perbedaan dalam kesederajatan baik secara individual maupun secara kultural dan kelompok. ${ }^{9}$ Dalam kelompok sosial, sekecil apapun kelompok ini jika direfleksikan dan dibaca nalar yang obyektif, maka multikultural akan diakui sebagai realitas termasuk model-modelnya.

${ }^{8}$ Undang-undang Republik Indonesia Nomor 14 tahun 2005 tentang Guru dan Dosen

${ }^{9}$ Hasan, Pendidikan Multikuturalisme, 10. 
Beberapa ahli sudah menempatkan multikulturalisme sebagai model. Artinya dalam model multikulturalisme ini, masyarakat Indonesia maupun masyarakat yang ada di bumi, khusunya yang kondisinya seperti Indonesia, mempunyai kultur yang berlaku general dalam masyarakat yang coraknya seperti suatu mozaik. Didalam mozaik itu tercakup semua kebudayaan dari masyarakatmasyarakat yang lebih kecil yang membentuk terwujudnya masyarakat yang lebih besar, yang mempunyai kultur seperti sebuah mozaik, multikuturalisme diperlukan dalam bentuk kontruksi kehidupan masyarakat dan bangsa, sehingga terwujud keharmonisan dalam keagamaan kultural atau berbudaya dalam realitas keragaman.

McCormik menyebutkan empat model multikulturalisme dalam konteks pembentukan suatu bangsa, yaitu:

a. Model melting pot, dalam pengertian peleburan etnisitasdan budaya menjadi sebuah bangsa baru, sehingga ciri-ciri etnisitas dan budaya lama yang membentuk kesatuan bangsa itu menjadi hilang.

b. Model assimilation, yaitu suatu pandangan yang membenarkan iliminasi perbedaan-perbedaan yang ada dan membaur dengan budaya kelompok yang dominan. Biasanya warna budaya kelompok dominan tersebut yang masih mudah dikenali meskipun sudah berkurang, sebaliknya budaya kelompok yang lemah akan menjadi kabur dan hilang.

c. Model salad bowi, yaitu memandang keharusan seorang individu atau kelompok dalam suau masyarakat harus menghormati keragaman kultural (cultural diversity) yang berasal dari etnis, budaya, agama, bahasa, dan wilayah dimana individu dan kelompok berasal, dan pada saat yang sama mendukung kesepakatan yang telah disetujui bersama untuk bersatu dan saling menghormati dalam satu wadah dan hidup berdampingan secara damai. Bangsa Indonesia mengikuti model ke-tiga ini dengan semboyan Bhineka Tunggal Ika.

d. Model open nation, suatu pandangan masyarakat terbuka, masyarakat dengan segala keberagamannya dibebaskan mengambil cara yang dikehendaki dalam membentuk suatu bangsa. 


\section{Pengertian Pendidikan Multikulturalsime}

Multikulturalisme ternyata bukanlah suatu pengertian yang mudah. Didalamnya mengandung dua pengertian yang sangat kompleks yaitu multi yang berarti plural, kulturalisme berisi pengertian kultur atau budaya. Istilah plural mengandung arti berjenis-jenis, karena pluralisme bukan bukan berarti sekedar pengakuan akan adanya hal-hal yang berjenis-jenis tetapi juga pengakuan tersebut mempunyai implikasi-implikasi politis, sosial, ekonomi. ${ }^{10}$ James Banks menyatakan bahwa pengertian pendidikan multikultural sebagai pendidikan untuk people of color. ${ }^{11}$ Pengertian ini senada dengan pengertian yang dikemukakan oleh Sleeter bahwa pendidikan multikultural adalah sekumpulan proses yang dilakukan oleh sekolah untuk menentang kelompok yang menindas. ${ }^{12}$ Pengertianpengertian ini tidak sesuai dengan konteks pendidikan di Indonesia karena Indonesia memiliki konteks budaya yang berbeda dari Amerika Serikat walaupun keduanya memiliki bangsa dengan multi-kebudayaan. Andersen dan Cusher mengatakan bahwa pendidikan multikultural adalah pendidikan mengenai keragaman kebudayaan. Definisi ini lebih luas dibandingkan dengan yang dikemukakan di atas. Meskipun demikian, posisi kebudayaan masih sama dengan apa yang dikemukakan dalam definisi di atas.

Rangkaian kata pendidikan dan multikultural memberikan arti secara terminologis adalah proses pengembangan seluruh potensi manusia yang menghargai pluralitas dan heterogenitasnya sebagai konsekwensi keragaman budaya, etnis, suku dan aliran (baca: agama). Zakiyuddin Baidhawi mendefinisikan pendidikan multikultural adalah suatu cara untuk mengajarkan keragaman (teaching diversity). ${ }^{13}$

Mundzier Suparta dalam bukunya Islamic Multicultural Education, mencatat lebih dari sepuluh definisi tentang pendidikan multikultural, diantaranya adalah;

10 Tilaar, Multikulturalisme, 82.

11 JamesBanks, "Multicultural Education: Historical Development, Dimensions, and Practice", Review of Researchin Education, 1993, 3.

12 Sleeter, dalam G.Burnett, Varieties of Multicultural Education: an Introduction (Ericlearing houseon Urban Education, Digest, 1994), 1.

13 Zakiyuddin Baidawi, Pendidikan Agama Berwawasan Multikultural (Jakarta: Erlangga, 2005), 8. 
pertama, pendidikan Multikultural adalah sebuah filosofi yang menekankan pada makna penting, legitimasi dan vitalitas keragaman etnik dan budaya dalam membentuk kehidupan individu, kelompok maupun bangsa. Kedua, pendidikan multikultural adalah menginstitusionalkan sebuah filosofi pluralisme budaya ke dalam sistem pendidikan yang didasarkan pada prinsip-prinsip persamaan (equality), saling menghormati dan menerima, memahami dan adanya komitmen moral untuk sebuah keadilan sosial. Ketiga, pendidikan multikultural adalah sebuah pendekatan pengajaran dan pembelajaran yang didasarkan atas nilai-nilai demokratis yang mendorong berkembangnya pluralisme budaya; dalam hampir seluruh bentuk komprehensifnya. Pendidikan multikultural merupakan sebuah komitmen untuk meraih persamaan pendidikan, mengembangkan kurikulum yang menumbuhkan pemahaman tentang kelompok-kelompok etnik dan memberangus praktik-praktek penindasan. Keempat, pendidikan multikultural merupakan reformasi sekolah yang komprehensif dan pendidikan dasar untuk semua anak didik yang menentang semua bentuk diskriminasi dan intruksi yang menindas dan hubungan antar personal di dalam kelas dan memberikan prinsipprinsip demokratis keadilan sosial. ${ }^{14}$

\section{Konsep dan Tujuan Pembelajaran Multikultural}

Pembelajaran multikultural merupakan strategi pendidikan yang memanfaatkan keberagaman latar belakang kebudayaan dari para peserta didik sebagai salah satu kekuatan untuk membentuk sikap multikultural. Pada dasarnya pembelajaran multikultural merupakan program pendidikan bangsa agar komunitas multikultural dapat berpartisipasi dalam mewujudkan kehidupan demokrasi yang ideal bagi bangsanya. ${ }^{15}$ Jika dilihat dari lintas sejarah hal tersebut sesuai dengan apa yang diajarkan oleh Rasulullah SAW tentang upaya untuk menegakkan keadilan pada semua komunitas, etnis dan agama yang ada sehingga tercapai kedamaian dan ketentraman. ${ }^{16}$ Sangat menarik bahwa Nabi Muhammad sendiri mengatakan bahwa,

\footnotetext{
${ }^{14}$ Taufiq Maftuhi, Modul I Buku Pengayaan Madrasah Multikultural (Kementerian Agama RI: 2016), 135.

${ }^{15}$ Yaya Suryana, Pendidikan Multikultural (Bandung: CV. Pustaka Setia, 2015), 282.

${ }^{16}$ Fuad Tohari, Modul II Buku Pengayaan Madrasah Multikultural (Kementerian Agama RI : 2016), 137.

134 | Tarbiyatuna: Jurnal Pendidikan Islam; Volume 11, Nomor 2, Agustus 2018 p-ISSN: 2085-6539; e-ISSN: 2242-4579
} 
kemuliaan seorang mukmin itu diukur dari agamanya,kehormatannya diukur dari akalnya dan martabatnya diukur dari akhlaknya. ${ }^{17}$

Dengan demikian konsep pembelajaran multikultural adalah proses pendidikan yang dapat membimbing, membentuk, dan mengkondisikan siswa agar memiliki mental atau karakteristik terbiasa hidup di tengah-tengah perbedaan yang sangat kompleks, baik perbedaan ideologi, perbedaan sosial, perbedaan ekonomi, maupun perbedaan agama. Dengan pembelajaran multikultural para lulusan akan memiliki sikap kemandirian dalam menyadari dan menyelesaikan segala masalah kehidupannya.

Berdasarkan tujuan pendidikan multikultural, terdapat tiga macam tujuan, yaitu tujuan yang berkaitan dengan sikap, pengetahuan, dan pembelajaran.

1. Aspek sikap (attitudinal goals), yaitu untuk mengembangkan kesadaran dan kepekaan kultural, toleransi kultural, penghargaan terhadap identitas kultural, sikap responsif terhadap budaya, ketrampilan untuk menghindari dan meresolusi konflik.

2. Aspek pengetahuan (cognitive goals), yaitu untuk memperoleh pengetahuan tentang bahasa dan budaya orang lain, dan kemampuan untuk menganalisis dan menerjemahkan perilaku kultural, serta pengetahuan tentang kesadaran perspektif kultur.

3. Aspek pembelajaran (intructional goals), yaitu untuk memperbaiki distorsi, stereotype, dan kesalahpahaman tentang kelompok etnik dalam buku teks dan media pembelajaran, memberikan berbagai strategi untuk mengarahkan perbedaan di depan orang, memberikan alat-alat konseptual untuk komunikasi antar budaya, mengembangkan ketrampilan interpersonal, memberikan teknik-teknik evaluasi, membantu klarifikasi nilai, menjelaskan dinamika kultural. ${ }^{18}$

4. Kegiatan belajar mengajar bukan ditujukan agar peserta didik menguasai sebanyak mungkin materi ilmu atau nilai, melainkan cara setiap pesrta didik mengalami sendiri proses berilmu serta hidup diruang kelas dan lingkungan sekolah. Pendidikan multikultural membantu siswa mengerti, menerima, dan menghargai

${ }^{17}$ Fakhrurrozi, Modul III Buku Pengayaan Madrasah Multikultural (Kementrian Agama RI: 2016), 82.

18 Suryana, Pendidikan Multikultural, 283. 
orang daru suku, budaya, dan nilai berbeda. Oleh sebab itu anak didik perlu diajak melihat nilai budaya lain sehingga mengerti secara dalam dan dapat menghargainya. Modelnya bukan dengan menyembunyikan budaya lain atau menyeragamkan sebagai budaya nasional sehingga budaya lokal hilang.

\section{Pentingnya Model-model Pendidikan Multikultural}

Bangsa Indonesia menganut falsafah yang majemuk, yaitu Bhineka Tunggal Ika. Hal ini mengandung makna yang sangat dalam serta luas bagi pengembangan kerukunan dan keutuhan hidup. Prinsip ke-bbineka-an didasari oleh pemikiran mengenai keragaman bahasa, tradisi dan budaya, serta agama Tanah Air dari Sabang sampai Merauke. Pengembangan pendidikan multikultural sangat tepat dalam menggambarkan realita yang ada. Pendidikan menjadi sumber dan tolok ukur seberapa jauh sebuah negara mampu bersaing di dunia internasional. Semakin baik mutu pendidikan yang dimiliki suatu negara, negara tersebut semakin siap bersaing di kancah global. Sebaliknya, semakin rendah mutu pendidikan suatu negara, negara tersebut semakin terpurukdan tersingkirkan dari perhelatan dunia global. ${ }^{19}$

\section{Nilai-nilai multikulturalisme dalam Pendidikan Agama Islam}

Keragaman-keragaman yang ada, sering disebutkan dengan istilah yang berbeda-beda, mengungkapkan bahwa adat iga istilah yang sering digunakan untuk menggambarkan masyarakat yang terdiri dari agama, ras, bahasa, dan budayayangberbeda, yaknipluralitas(plurality), keragaman(diversity),danmultikultural (multicultural). Ketiga-tiganyasama-samamerepresentasikanhalsama yaitu keadaan lebih dari satu atau jamak. ${ }^{20}$

Memperhatikanrumusan pengertian para pakar di atas dapat disimpulkan bahwa pendidikanmultikulturaladalahpendidikanyang dibangunberdasarkan nilai-nilai inti dan sikap sosialtertentu. Matrik1 menyebut ada 3 nilai inti yang terdapat dalam pendidikan multikultural, yaitu: pertama,nilai demokrasi, kesetaraan, dan keadilan; kedua, nilai kemanusiaan, kebersamaan, dan kedamaian; ketiga,sikap 
sosial, yaitu: pengakuan, penerimaan, dan penghargaan kepada orang lain. $^{21}$

1. Nilai Demokrasi, Kesetaraan, dan Keadilan

\begin{tabular}{|c|l|l|}
\hline No & \multicolumn{1}{|c|}{ Nilai Inti Multikultural } & \multicolumn{1}{c|}{ Deskripsi } \\
\hline 1. & $\begin{array}{l}\text { Demokrasi, Kesetaraan dan } \\
\text { Keadilan }\end{array}$ & $\begin{array}{l}\text { Nilai ini ada dalam al-Qur'an surat al- } \\
\text { Baqarah [2]: 256 dan al-Käfirūn[109]: 1-6. }\end{array}$ \\
\cline { 3 - 4 } & $\begin{array}{l}\text { Telah dipraktikkan oleh Rasulullah saw. } \\
\text { untuk mengelola keragaman kelompok } \\
\text { dalam masvarakat di Mekah dan Madinah. }\end{array}$ \\
\hline 2. & Kemanusiaan, Kebersamaan, & $\begin{array}{l}\text { Ditemukan keberadaannya dalam al-Qur'an } \\
\text { Surat al- Hujurāt: 13 dengan doktrin saling } \\
\text { mengenal (ta'aruf) dan saling menolong } \\
\text { (ta'awun) untuk membangun hubungan } \\
\text { danial vang baik. }\end{array}$ \\
\hline
\end{tabular}

Ketiga nilai ini merupakan keniscayaan bagi masyarakat yang majemuk. Ketiga nilai inimenggaris bawahibahwa semuaanggota masyarakat memiliki hak yang sama untuk memperoleh pendidikan. Di beberapa negara berkembang seperti Afrika, Banglades, Brazil, China, Mesir, India, Indonesia, Mexico, Nigeria, dan Pakistan. menurut hasil survey UNESCO pada 2004 menunjukkan bahwa kesempatan memperoleh pendidikan masih terbatas pada anak dari keluarga kelas menengah keatas. Anak- anak dari keluarga miskin belum memperoleh kesempatan yang luas untuk mengenyam pendidikan. Fakta ini tentu bertolak belakang dengan nilai demokrasi, kesetaraan, dan keadilan dalam pendidikan multikultural.

Nilai demokrasi, kesetaraan, dan keadilan ini sejalan dengan program UNESCO tentang education for all (EFA), yaitu program pendidikan yang memberikan peluang yang sama kepada semua anak untuk memperoleh pendidikan. Program pendidikan untuk semua ini, menurut Lyn Haas, sebenarnya tidak hanya terbatas pada pemberian kesempatan yang sama kepada semua anak untuk memperoleh pendidikan, melainkan juga berarti bahwa semua peserta didik harus memperoleh perlakuan yang sama untuk memperoleh

${ }^{21}$ Abdullah Aly,"Studi Deskriptif Nilai-nilai Multikultural dalam pendidikan di Pondok Pesantren Modern Islam Assalam,'Jurnal Islamiah Pesantren, Surakarta. Vol. 1, 2015. 
pelajaran di dalam kelas.

Kesetaraan diartikulasikan pada sebuah tingkatan yang saling terkait. Pada level paling dasar kesetaraan melibatkan penghargaan, pada level sedikit lebih tinggi melibatkan kesempatan, kepercayaan diri, harga diri,dan lainnya. Pada lebel yang tinggi lagi kesetaraan melibatkan kekuasaan. ${ }^{22}$

Jika dilihat dari perspektif Islam, nilai demokrasi, kesetaraan, dan keadilan ini ternyata kompatibel dengan doktrin-doktrin Islam dan pengalaman historis umat Islam, terutama pada abad klasik. Adapun doktrin Islam yang mengandung nilai demokrasi, kesetaraan, dan keadilan, antara lain, ditemukan keberadaannya dalam al-Qur'ān surat al-Baqarah 2: 256 dan al-Kāfirūn 109: 1-6. ${ }^{23}$ Nilai demokrasi ini memberikan landasan moral dan etik bahwa setiap orang diberi hak untuk menentukan pilihannya terhadap agama. Islam tidak mengajarkan doktrin pemaksaan untuk memilih agama tertentu oleh suatu pihak terhadap pihak yang lain. Prinsip ini memberikan isyarat bahwa Islam tidak mengajarkan doktrin rasisme, yang menempatkan suatu kelompok secara superior atas kelompok yang lain karena faktor ras dan etnik. Dalam hubungan ini, Rasulullah SAW. menegaskan bahwa tidak ada keutamaan orang Arab atas orang bukan Arab, tidak ada keutamaan orang bukan Arab atas orang Arab, orang hitam atas orang berwarna, orang berwarna atas orang hitam, kecuali karena takwanya. Sementara itu, dalam hal beragama, Islam memperkenalkan doktrin bagimu agamamu dan bagiku agamaku.

Doktrin Islam tentang nilai demokrasi, kesetaraan, dan keadilan di atas telah dipraktikkan oleh Rasulullah saw. untuk mengelola keragaman kelompok dalam masyarakat di Madinah. Pada saat pertama kali memasuki kota Madinah, misalnya, Nabi saw. membuat perjanjian tertulis yang populer dengan sebutan Piagam Madinah. Piagam ini menetapkan seluruh penduduk Madinah memperoleh status yang sama atau persamaan dalam kehidupan.

2. Nilai Kemanusiaan, Kebersamaan, dan Kedamaian

Dalam beberapa studi disebutkan bahwa nilai-nilai kemanusiaan,

22 Bikhu Parekh, Rethinking Multikulturalism (Yogyakarta: Kanisius, 2008), 319.

23 Al-Qur'an, 2: 256; 109: 1-6

138 | Tarbiyatuna: Jurnal Pendidikan Islam; Volume 11, Nomor 2, Agustus 2018 p-ISSN: 2085-6539; e-ISSN: 2242-4579 
kebersamaan, dan kedamaian merupakan nilai-nilai universal yang dibutuhkan oleh setiap orang dalam masyarakat majemuk. Nilai kemanusiaan adalah spirit yang menempatkan manusia dalam posisi tertinggi dan bermartabat. Sebagai manusia bermartabat, Nimrod Aloni menyebut adanya 3 (tiga) prinsip dalam kemanusiaan, yaitu: pertama, otonomi, rasional, dan penghargaan untuk semua orang; kedua,kesetaraan, kesalingan, dan kebersamaan; ketiga, komitmen untuk membantu semua orang dalam pengembangan potensinya.

Kehidupan sosial yang harmonis dan penuh dengan kedamaian ini ternyata kompatibel dengan doktrin Islam tentang as-salam. Doktrin ini mengandung pengertian bahwa Islam menawarkan visi hidup yang harmonis, damai, dan sejahtera di tengah-tengah kelompok masyarakat yang beragam. Antara lain melalui al-Qur'an surat al-Nahl:125 dan Fușșilat:34. ${ }^{24}$

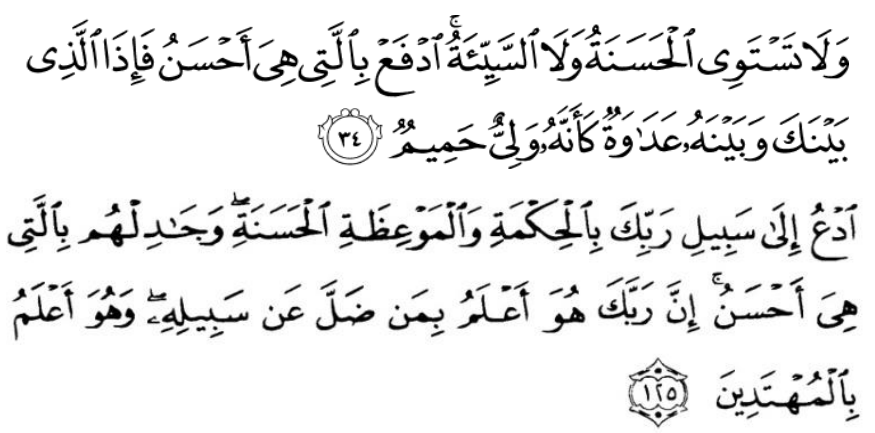

Menolak adanya sikap hidup yang membedakan antara 'kita' dan 'mereka'. Karena berdasarkan kedua ayat tersebut, seorang musuh merupakan sosok yang potensial untuk bisa menjadi teman. Doktrin Islam al-salām tentang visi hidup yang harmonis, damai, dan sejahtera ini diperkuat oleh doktrin Islam yang lain, yaitu doktrin tentang kesatuan komunitas manusia.

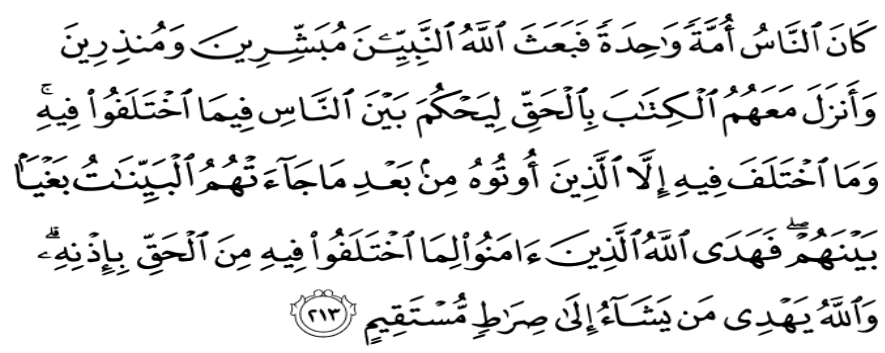

${ }^{24}$ Al-Qur'an, 16:125; 41:34 
Doktrin ini secara eksplisit ditemukan keberadaannya dalam al-Qur'an surat al-Baqarah: 213.25. Doktrin ini menurut Abdul Aziz Sachedina mengandung 3 (tiga) pesan moral, yaitu: pertama, bahwa manusia pada dasarnya adalah satu dengan Satu Tuhan, kedua, bahwa kesatuan kemanusiaan itu diikat oleh. Agama-agama yang dibawa oleh para nabi, dan ketiga, bahwa fungsi wahyu itu sebagai sarana untuk memecahkan perbedaan-perbedaan yang terjadi dalam komunitas antariman.

3. Sikap Mengakui, Menerima, dan Menghargai Keragaman

Kehidupan di masyarakat yang majemuk diperlukan sikap sosial yang positif. Sikap sosial positif ini antara lain mengambil bentuk kesediaan untuk mengakui, menerima, dan menghargai keragaman. Pendidikan multikultural memiliki perhatian kuat terhadap pengembangan sikap-sikap sosial yang positif tersebut.

Sikap menerima, mengakui, dan menghargai keragaman yang akan dikembangkan oleh pendidikan multikultural ini secara teoritik merupakan inti dari konsep koeksistensi dan proeksistensi. Koeksistensi berarti individu atau kelompok menerima secara berdampingan dan memberikan ruang kepada orang atau kelompok lain yang berbeda latar belakang agama, etnik, budaya, dan bahasanya. Sikap ini dapat dikembangkan melalui toleransi, empati, simpati, keterampilan sosial dan menjauhkan diri dari sikap prejudice dan stereotype kepada orang lain dalam kehidupan sehari-hari. Sementara itu, sikap pro-eksistensi dapat dipahami sebagai memberikan apresiasi dan dukungan terhadap kegiatan yang dilakukan oleh orang atau kelompok lain yang berbeda latar belakang agama, etnik, bahasa, dan budaya. Dalam arti ini, masing-masing individu tidak hanya menerima kehadiran orang atau kelompok lain, melainkan juga proaktif dengan menghargai, mendukung, dan turut mengupayakan kehadirannya. Konsep koeksistensi dan pro-eksistensi ini sejalan dengan salah satu doktrin Islam tentang pentingnya menjaga perasaan orang lain, dan berlaku baik kepada tetangga (H.R. Muslim). Dasar normatif lainnya terkait 
dengan doktrin tentang pentingnya senyuman, keramahtamahan, kasih sayang, memberi maaf. ${ }^{26}$

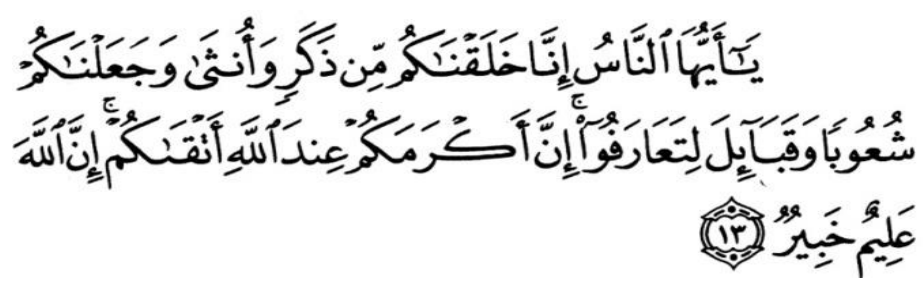

\section{Pendidikan Agama Islam}

Istilah pendidikan dalam Islam sering diungkapkan dalam bentuk al-tarbiyah, al-ta'lim, al-ta'dib dan al-riyạ̈̆ah. Setiap term tersebut memiliki makna yang berbeda, kerena disebabkan perbedaan konteks kalimatnya, walaupun demikian dalam hal-hal tertentu term-term tersebut memiliki makna yang sama. ${ }^{27}$ Tarbiyah brasal dari kata rabbā, yurabbi tarbiyatan yang memiliki makna tambah (zad) dan berkembang (numu). Pengertian misalnya terdapat dalam surat al-Rūm (30) ayat (39) berdasarkan pada ayat tersebut, maka al-Tarbiyah dapat berarti proses menumbuhkan dan mengembangkan apa yang sudah ada pada diri peserta didik baik secara fisik, psikis, sosial, maupun spiritual. ${ }^{28}$ Sedangkan kata al-ta'Tim merupakan bentuk bagian kecil dari al-tarbiyah yang bertujuan memperoleh ilmu pengetahuan dan keahlian berfikir, yang sifatnya mengacu pada domain kognitif. Terdapat beberapa pemikir pendidikan yang mengartikan al-ta'lim dalam konteks pendidikan. Diantaranya, M.Rasyid Ridlo yang mendefinisikan al-ta'lim dengan proses transmisi ilmu pengetahuan pada jiwa individu tanpa ada batasan dan ketentuan tertentu. ${ }^{29}$ Yang ke-tiga adalah at-ta'dib sebagaimana dijumpai dalam hadith Nabi memiliki pengertian pengenalan dan pengakuan yang secara berangsur-angsur ditanamkan kepada manusia tentang tempat-tempat yang tepat dari segala sesuatu didalam tatanan penciptaan sedemikian rupa, sehingga membimbing kearah perkenalan dan pengakuan kekuasaan dan keagungan Allah di dalam tatanan Wujud dan keberadaannya. ${ }^{30}$

\footnotetext{
26 Al-Qur'an, 12:92

27 Heri Gunawan, Kurikulum dan Pembelajaran Pendidikan Agama Islam (Bandung: Alfabeta, 2013), 198.

28 Abuddin Nata, Ilmu Pendidikan Islam (Jakarta: Kencana, 2010), 8.

29 Gunawan, Kurikulum dan Pembelajaran, 199

30 Gunawan, Kurikulum dan Pembelajaran, 201
} 
Secara terminologis pendidikan Agama Islam adalah proses mempersiapkan manusia supaya hidup dngan sempurna dan bahagia, mencintai tanah air, dan tegap jasmaninya, sempurna budi pekertinya, tratur pikirannya, halus perasaannya, manis tutur katanya, baik dngan lisan maupun tulisan. Di dalam GBPP PAI di sekolah umum, dijlaskan bahwa pendidikan Agama Islam adalah usaha sadar untuk menyiapkan siswa dalam meyakini, memahami, menghayati, dan mengamalkan Agama Islam melalui kegiatan bimbingan, pengajaran, dan/atau latihan dngan memperhatikan tuntutan untuk menghormati agama lain dalam hubungan kerukunan antar umat beragama dalam masyarakat untuk mewujudkan persatuan nasional. ${ }^{31}$

Dari pengertian tersebut dapat ditemukan beberapa hal yang perlu diperhatikan dalam pembelajaran pendidikan agama Islam, antara lain:

a. Pendidikan Agama Islam sebagai usaha sadar, yakni suatu kegiaatan bimbingan, pengajaran, dan/atau latihan yang dilakukan scara berencana dan sadar atas tujuan yang hndak dicapai.

b. Peserta didik yang hendak disiapkan untuk mencapai tujuan dalam arti ada yang dibimbing, diajari, dan/atau dilatih dalam peningkatan keyakinan, pemahaman, penghayatan, dan pengamalan terhadap ajaran agama Islam.

c. Pendidik atau Guru Pendidikan Agama Islam (GPAI) yang melakukan kgiatan bimbingan, pengajaran dan/atau latihan secara sadar terhadap pesrta didiknya untuk mencapai tujuan pendidikan agama Islam.

d. Kegiatan (baca: pembelajaran) pendidikan agama Islam diarahkan untuk meningkatkan keyakinan, pemahaman, penghayatan, dan pengamalan ajaran agama Islam dari peserta didik, yang disamping untuk membentuk kesalehan atau kualitas pribadi, sekaligus untuk membentuk kesalehan sosial. Dalam arti kualitas atau kesalehan pribadi itu diharapkan mampu memancar ke luar dalam hubungan keseharian dengan manusia lainnya (bermasyarakat), baik sesama muslim ataupun non muslim, serta dalam berbangsa dan bernegara sehingga dapat terwujud persatuan dan kesatuan nasional (ukhuwah wataniyah) dan bahkan (ukhuwah insāniyah) persatuan dan kesatuan atar sesama manusia.

31 Muhaimin, Paradigma Pendidikan Islam (Bandung: PT Remaja Rosdakarya, 2008), 75

142 | Tarbiyatuna: Jurnal Pendidikan Islam; Volume 11, Nomor 2, Agustus 2018 p-ISSN: 2085-6539; e-ISSN: 2242-4579 
Secara umum tujuan pendidikan agama Islam adalah untuk meningkatkan keimanan, pemahaman, penghayatan dan pengalaman peserta didik tentang agama Islam, sehingga mnjadi manusia muslim yang beriman dan bertaqwa kepada Allah SWT serta berahlak mulia dalam kehidupan pribadi, bermasyarakat, berbangsa dan bernegara. ${ }^{32}$

Kalau kita melihat kembali pengertian pendidikan agama Islam, akan terlihat dengan jelas suatu yang diharapkan terwujud setelah orang mengalami pendidikan Islam secara kesluruhan, yaitu kepribadian seseorang yang membuatnya menjadi "insan kamil" dengan pola taqwa insan kamil artinya manusia utuh rohani dan jasmani, dapat hidup dan berkembang secara wajar dan normal karena taqwanya kepada Allah SWT. Ini mengandung arti bahwa pendidikan agama Islam itu diharapkan menghasilkan manusia yang berguna bagi dirinya dan masyarakat serta senang dan gemar mengamalkan dan mengembangkan ajaran Islam dalam berhubungan dengan Allah dan dengan sesama manusia serta dapat mengambil manfaat yang semakin meningkat dari alam semesta ini untuk kepentingan hidup di dunia dan di akhirat. ${ }^{33}$

Bertolak dari pembahasan diatas menunjukkan bahwa, pendidikan Islam mempunyai cakupan pembahasan yang sangat luas yang mengandung unsur aktivitas dan sekaligus fenomena. ${ }^{34}$

\section{Implementasi Nilai-nilai Multikulturalisme dalam Pendidikan Agama Islam}

Dalam dialog peserta didik dibimbing dan diperkenalkan cara-cara menyelesaikan masalah sosial, agama dan akibat keanekaragaman pada masyarakat multikultural dengan cara:

1. Mengintegrasikan unsur-unsur sosial seperti perbedaan ras, suku dan agama. Upaya pengintegrasian dapat dilakukan melalui kegiatan organisasi. Misalnya OSIS, karang taruna dan lain sebagainya.

2. Mengembangkan budaya nasional yang bersumber dari budaya daerah.

3. Mengembangkan sikap tenggang rasa antar unsur sosial.

\footnotetext{
32 Muhaimin, Paradigma Pendidikan Islam, 78.

33 Zakiyah Darajat, Ilmu Pendidikan Islam (Jakarta: PT Bumi Aksara, 2016), 30.

${ }^{34}$ Mujtahid, Reformasi Pendidikan Islam (Malang: UIN Maliki, 2011), 19.
} 
4. Mengembangkan wawasan kebangsaanmeletakkan landasan tentang HAM.

5. Membangun sikap toleransi antar umat beragama.

Dalam rangka menumbuhkan dan mengembangkan toleransi antar umat beragama, peserta didik harus menghindari dan menjauhi beberapa sikap, yaitu :

1. Fanatisme yang berlebihan.

2. Mencampuradukkan ajaran suatu agama/kepercayaan dengan agama/kepercayaan lain.

3. Mencampuri urusan internal agama/kepercayaan lain. ${ }^{35}$

\section{Faktor Pendukung dan Faktor Penghambat Implementasi Nilai Multikulturalisme dalam Pendidikan Agama Islam.}

Faktor pendukung implementasi nilai multikultural dalam pendidikan agama Islam antara lain:

1. Adanya landasan theologis dari al-Qur'an maupun hadist terhadap nilai-nilai multikulturalisme.

2. Nilai-nilai multikultural telah lama dikenaldan diajarkan di lembaga pendidikan Islam.

3. Rakyat Indonesia telah memiliki sejarah yang panjang mengenai pluralisme dan multikulturalisme, karena Indonesia dikenal sebagai negara religius dan multikultur.

4. Terbentuknya (FKUB) Forum Kerukunan Umat Beragamauntuk memecahkan kbekuan komunikasi dan kerjasama antar umat beragama.

Faktor penghambat implementasi nilai-nilai multikultural dalam pendidikan agama Islam antara lain:

1. Masih terbangunnya mindset (kerangka berpikir) yang keliru dalam memahami aliran-aliran kontemporer dengan ajaran agam.

2. Masih merebaknya konflik antar umat beragama

3. Lebih menonjolkan semangat ke-Ika-an dari pada ke-Bhineka-an dalam kehidupan berbangsa dan bernegara srta kurangnya pngakuan terhadap keberadaan agama, suku, dan golongan lain. 
4. Belum tertanam bahwa menganggap agama, kelompok/suku yang satu "lebih baik" dari yang lain adalah pandangan yang sempit dan offensive.

\section{Nilai Multikulturalisme yang ada di SMA Negeri 3 Lumajang}

Nilai multikultural yang ada di SMA Ngeri 3 Lumajang dibuktikan dengan tidak adanya konflik sosial. Karena keberagaman itu bermacam-macam, ada keberagaman agama, suku, budaya, dan etnis. Jika dilihat dari keberagaman agama mayoritas muslim tapi juga ada yang non-muslim, secara otomatis keberagaman agama tersebut menyebabkan keberagaman budaya. Sekalipun terdapat perbedaan agama mereka dapat hidup dengan berdampingan dan tidak pernah membedabedakan satu sama lain bahkan mereka yang berbeda agama saling membantu satu sama lain sehinggia tidak terjadi diskriminasi antara yang mayoritas dengan yang minoritas. $^{36}$

Sekolah juga memfasilitasi sarana dan prasarana sehingga mereka mendapatkan kesempatan seluas-luasnya untuk melakukan kegiatan keagamaannya sesuai dengan agama masing-masing. Budaya dan entis yang ada di SMA Negeri 3 lumajang juga bermacam-macam ada etnis madura dan etnis jawa, dari sisi interaksi sosial tidak ada masalah dengan perbedaan tersebut juga tidak menjadi halangan untuk berinteraksi antar sesama bahkan menjadikan kolaborasi yang baik. Jadi di SMA Negeri 3 Lumajang tidak ada diskriminasi meskipun terdapat banyak perbedaan bahkan dapat hidup bersama dalam suasana kekeluargaan. ${ }^{37}$

Berdasarkan hasil observasi peneliti, SMA Negeri 3 Lumajang memiliki aturan baku yang ditetapkan dan harus ditaati oleh siapapun di sana. Perbedaan agama dan budaya melebur menjadi nilai-nilai positif yang ditaati bersama. Hal ini menunjukkan bahwa di SMA Negeri 3 nilai multikultural diimplementasikan dalam tata tertib, tanpa membeda-bedakan agama dan ras sebagai salah satu bentuk nilai keadilan dan kesetaraan.

Implementasikan nilai-nilai multikultralisme dalam pendidikan agama Islam di SMA Negeri 3 Lumajang dilakukan didalam kelas ketika proses belajar mengajar.

\footnotetext{
36 Ahmad Amrullah, Wawancara, Guru Pendidikan Agama Islam SMA Negeri Lumajang, 20 Maret 2018

${ }^{37}$ Siti, Wawancara, Wakil Kepala Bidang Hubungan Masyarakat, 20 Maret 2018
} 
Selanjutnya diamalkan dalam kehidupan sehari-hari di lingkungan sekolah, sehingga menjadi pembiasaan yang baik. ${ }^{38}$ Dalam hal beda suku dan budaya, implementasi nilai multikultural dilakukan Kegiatan pembiasaaan ini meliputi: pertama, budaya berjabat tangan dengan sesama teman yang sejenis dan kepada guru; kedua, bekerja kelompok; ketiga, budaya 5S yakni, senyum, salam, sapa, sopan dan santun;keempat, berdiskusi; kelima, budaya antri.

Dalam penanaman nilai multikultural yang didalam terdapat nilai kebersamaan, kesamaan, kesetaraan, demokarasi dan keadilan dilakukan dengan berbagai tahap-tahap, guru PAI mengimpimplementasikan nilai multikulturalisme dalam beberapa tahapan, hal tersebut dilakukan agar nilai multikulturalisme tertanam dalam jiwa seluruh pesrta didik, dalam mengimplementasikan nilai tersebut hal yang pertama dilakukan adalah dengan melakukan: pertama, pengenalan terlabih dahulu; kedua, pemahaman; ketiga, pembiasaan, yakni melalui kegiatan atau hal yang biasa dilakukan di sekolah yang telah menjadi budaya yang erat kaitannya dengan nilai multikulturalisme. Misalkan budaya tegur sapa antar sesama tanpa memandang perbedaan agama,suku dan etnis, melaksanakan budaya antri karena beranggapan bahwa semuanya sama dan setara tidak ada yang istimewa dan tidak membedabedakan status sosial. ${ }^{39}$

Diantara sekian proses impelmentasi multikultural, terdapat factor pendukung, antara lain karena antusias peserta didik. Antusias peserta didik dalam mengikuti setiap kegiatan pembiasaan yang dilakukan di SMA Negeri 3 Lumajang merupakan modal utama yang dapat digunakan untuk mengimplementasikan nilainilai multikulturalisme dalam pendidikan agama Islam. Modal utama dalam mengimplementasikan nilai multikulturalisme dalam pendidikan agama Islam adalah kemauan dan partisipasi peserta didik. Bila kemauan dan dan partisipasi perserta didik sudah tertanam dalam benak peserta didik, maka kegiatan pembiasaan yang ada di SMA Negeri 3 Lumajang akan dengan mudah terlaksana. Selain itu, hal yang paling mendasar yaitu tumbuhnya kesadaran peserta didik dalam melaksanakan kegiatan pembiasaan menjadi pemicu utama antusias pesrta didik dalam mengikuti kegiatan

38 Yusuf Adurrahman, Wawancara, Guru Pendidikan Agama Islam SMA Negeri 3 Lumajang, 3 April 2018.

${ }^{39}$ Noor Juminato, Wawancara, Wakil Kepala Bidang Kurikulum, 19 April 2018.

146 | Tarbiyatuna: Jurnal Pendidikan Islam; Volume 11, Nomor 2, Agustus 2018 p-ISSN: 2085-6539; e-ISSN: 2242-4579 
pembiasaan yang ada di SMA Negeri 3 Lumajang dan didukung dengan adanya tata tertib sekolah. ${ }^{40}$

\section{Kesimpulan}

Nilai multikultural yang ada di SMA Negeri 3 Lumajang antara lain nilai kebersamaan, nilai keadilan, nilai kesamaan dan kesetaraan, meskipun terdapat perbedaan seperti perbedaan agama, suku, dan budaya tetap dapat hidup bersama dengan rukun dan harmonis, menjunjung tinggi toleransi dan menghargai perbedaan, hal tersebut dapat dibuktikan dengan tidak pernah ada konflik sosial dan pelecehan agama.Implementasi nilai multikultural dalam pendidikan agama Islam untuk dalam hal beda budaya dan suku dilakukan dengan membiasakan budaya berjabat tangan dengan guru, budaya 5S (salam, senyum, sapa, sopan santun), budaya antri, budaya bekerja kelompok, budaya diskusi. Sedangkan dalam hal beda agama dilakukan dengan memberikan fasilitas dan waktu khusus bagi pemeluk agama selain muslim untuk melakukan ibadah sesuai dengan agamanya sebagai bentuk dari implementasi sikap toleransi.

\section{Referensi}

Al-Qur'an. 2007. Solo: PT Qomari Prima Publisher.

Aly, Abdullah. 2015,'Studi Deskriptif Nilai-nilai Multikultural dalam pendidikan di Pondok Pesantren Modern Islam Assalam”,Jurnal Islamiah Pesantren.Vol 1.Surakarta

Amin, Kamaruddin. 2006. Quo Vadis Islamic Studies In Indonesia. Jakarta: Departemen Agama RI.

Baidhawy, Zakiyudi. 2005. Pendidikan Agama Berwawasan Multikultural. Jakarta: Erlangga.

Bank, James. 1993. Multicultural Education: Historical Development, Dimensions, And Practice. Review of Researchin Education.

Burnett, G. 1994. Varieties of Multicultural Education: an Introduction. Eric learing houseon Urban Education, Digest.

Darajat, Zakiyah. 2016. Ilmu Pendidikan Islam.Jakarta: PT. Bumi Aksara.

Dermawan, Pilan. 2015. Multikulturalise H.A.R Tilaar dalam Perspektif Pendidikan Islam, Yogyakarta: Tesis, Universitas Islam Negeri Sunan Kalijaga, Yogyakarta.

Fakhrurrozi. 2016. Modul III (Buku Pengayaan) Madrasah Multikultural. Jakarta: Kementerian Agama RI

Fatimah, Siti. 2016. Gender dan Pendidikan Multikultural. Jakarta: Kencana.

${ }^{40}$ Muhammad Jefri, Wawancara, siswa SMA Negeri 3 Lumajang, 3 April 2018. 
Fuad, Tohari. 2016. Modul II (BukuPengayaan) Madrasah Multikultural. Jakarta: Kementerian RI

Gunawan, Heri. 2013. Kurikulum dan Pembelajaran Pendidikan Agama Islam. Bandung: Alfabeta.

Hasan, Muhammad Tholchah. 2016. Pendidikan Multikultural Sebagai Opsi Penanggulangan Radikalisme. Malang : Lembaga Penerbitan Universitas Islam Malang.

Maftuhi, Taufiq. 2016. Modul I (buku pengayaan) Madrasah Multikultural. Jakarta: Kementerian Agama RI.

Muhaimin. 2008. Paradigma Pendidikan Islam. Bandung: PT. Remaja Rosdakarya.

Mujtahid. 2011. Reformasi Pendidikan Islam. Malang: UIN Maliki.

Mulyasa. 2002. Manajemen Berbasis Sekolah. Bandung: Remaja Rosdakarya.

Nasution, S. 1996. Metode Research (Penelitian Ilmiah), Jakarta: Bumi Aksara.

Nata, Abuddin. 2010. Ilmu Pendidikan Islam. Jakarta: Kencana.

Parekh, Bikhu. 2008. Rethinking Multikulturalism. Yogyakarta: Kanisius.

Purwadarminta, W, Js. 1999. Kamus Umum Bahasa Indonesia, Jakarta: Balai Pustaka.

Rohman, Miftahur. 2016. Implementasi Nilai Multikultural di MAN Yogyakarta dan Stela Duce 2 Yogyakarta (studi komparasi di sekolah berbasis islam dan kristen).Yogyakarta: Skripsi UIN Sunan Kalijaga Yogyakarta.

Ruslan, Ibrahim. 2008. "Pendidikan Multikultural", El Tarbawi Jurnal Pendidikan Islam,vol.1.

Suryana, Yaya. 2015. Pendidikan Multikultural. Bandung: CV Pustaka Setia.

Tilaar, H.A.R. 2004. Multikulturalisme, Jakarta: PT Grasindo.

Torang, Syamsir. 2012. Metode Riset Struktur dan Perilaku Organisasi, Bandung: Alfabeta.

Umar, Husein. 2007. Riset Manajemen Sumber Daya Manusia, Jakarta: Gramedia.

Undang-undang Republik Indonesia Nomor 14 tahun 2005 tentang Guru dan Dosen, Asa Mandiri, 2006.

Yakin, M. Ainul. 2005. Pendidikan Multikultural, Yogyakarta: Pilar Media. 